\title{
On the Effects of Manganese Oxide and Aluminum Oxide on the Viscosity of High Carbon Ferro-Manganese Slags
}

\author{
Isao TANABE*, Koichi OKu* and Tsugunori HondA*
}

\section{Introduction}

The effects of manganese oxide on the viscosity of high carbon ferro-manganese slag were reported in the previous paper ${ }^{1}$. The outline of experiments on the effects of manganese oxide and alumina is presented in this paper.

\section{Method of Measurement and Samples}

2.1 Method of measurement The apparatus used and the method of operation were just the same as in the previous report, and viscosity $\eta$ was calculated by the equation :

$$
\eta=A t+B
$$

2.2 Samples The effects of $\mathrm{MnO}$ were investigated by the following way: the mother slag of group $A$ in Table 1 was taken, and the measurement was made in the range of $5 \sim 30 \%$ of $\mathrm{MnO}$ with keeping the content of $\mathrm{Al}_{2} \mathrm{O}_{3}$ at $6 \%$. The effects of $\mathrm{Al}_{2} \mathrm{O}_{3}$ were investigated by the following way: the

Table 1 Chemical Composition of Mother Slags Used

\begin{tabular}{|c|c|c|c|c|c|c|c|}
\hline Group & No. & $\mathrm{MnO}$ & $\mathrm{Al}_{2} \mathrm{O}_{3}$ & $\mathrm{CaO}$ & $\mathrm{SiO}_{2}$ & $\mathrm{FeO}$ & $\mathrm{CaO} / \mathrm{SiO}_{2}$ \\
\hline \multirow{6}{*}{ A } & 1 & 5.00 & 6.00 & 34.71 & 53.93 & 0.36 & 0.64 \\
\hline & 2 & " & " & 39.42 & 49.21 & 0.37 & 0.80 \\
\hline & 3 & " & " & 42.80 & 45.89 & 0.31 & 0.93 \\
\hline & 4 & " & " & 46.56 & 42.21 & 0.23 & 1.10 \\
\hline & 5 & " & $"$ & 50.38 & 38.25 & 0.37 & 1.32 \\
\hline & 6 & " & $"$ & 52.48 & 36.20 & 0.32 & 1.45 \\
\hline \multirow{6}{*}{ B } & 1 & 10.00 & 3.00 & 33.96 & 52.68 & 0.36 & 0.64 \\
\hline & 2 & " & $"$ & 38.51 & 48.08 & 0.41 & 0.80 \\
\hline & 3 & " & " & 41.84 & 44.87 & 0.29 & 0.93 \\
\hline & 4 & " & $"$ & 45.46 & 41.21 & 0.33 & 1.10 \\
\hline & 5 & " & " & 49.25 & 37.32 & 0.43 & 1.32 \\
\hline & 6 & " & " & 51.27 & 35.40 & 0.33 & 1.45 \\
\hline
\end{tabular}

mother slag of Group $B$ in Table 1 was taken, and the measurement was made in the range of 3 20\% of $\mathrm{Al}_{2} \mathrm{O}_{3}$ with keeping the content of $\mathrm{MnO}$ at $10 \%$.

The contents of $\mathrm{MnO}$ and $\mathrm{Al}_{2} \mathrm{O}_{3}$ were adjusted in such a way that the calculated quantities of almost pure $\mathrm{MnO}$ and $\mathrm{Al}_{2} \mathrm{O}_{3}$ were blended with the mother slag in Table 1 to make the required compositions.

\section{Results and Discusion}

3. Effects of $\mathrm{MnO}$ The results obtained at 1400,1350 and $1300^{\circ} \mathrm{C}$ are summarized in Table 2 . The relation between $\eta$ and $\mathrm{MnO}$ content at $1400^{\circ} \mathrm{C}$ which was classified according to the basicity was shown in Fig. 1. The relation between $\log \eta$ and basicity which was classified acconding to the $\mathrm{MnO}$ content was shown in Fig. 2. From these results, the effects of $\mathrm{MnO}$ on $\eta$ are summarized as follows :

(1) In composition with basicity less than $1.0, \eta$ decreases rapidly with increasing content of $\mathrm{MnO}$, and no increase of $\eta$ is observed in the case of $\mathrm{MnO}$ content under $30 \%$. While, in the composition with basicity more than $1.1, \eta$ decreases with increasing content of $\mathrm{MnO}$ up to $20 \sim 25 \%$, but it rather increases with higher content of $\mathrm{MnO}$. These tendensies are more remarkable at higher basicity.

(2) In the range of $\mathrm{MnO} 5 \sim 10 \%, \eta$ has minimum values with basicity of $1.0 \sim 1.1$, but the range

* Lab. of Azuma Kako \& Co., Ltd., Fushiki-Kushioka, Takaoka, Toyama

The original written in Japanese can be seen in J. Electrochem. Soc. Japan 28, 681 (1960). 
Table 2 Effect of $\mathrm{MnO}$ Content

\begin{tabular}{|c|c|c|c|c|c|c|c|c|c|c|c|c|}
\hline \multirow{3}{*}{ Group } & \multirow{3}{*}{$\mathrm{CaO} / \mathrm{SiO}_{2}$} & \multirow{3}{*}{$\mathrm{MnO}$} & \multirow{2}{*}{\multicolumn{3}{|c|}{$\eta$ (poise) }} & \multicolumn{6}{|c|}{$\ln \eta=Q / R T+C$} & \multirow{3}{*}{$\begin{array}{l}\text { Inversion } \\
\text { points }\left({ }^{\circ} \mathrm{C}\right)\end{array}$} \\
\hline & & & & & & \multicolumn{3}{|c|}{$Q(\mathrm{kcal})$} & \multicolumn{3}{|c|}{$-C \cdot \log _{10} e$} & \\
\hline & & & $1400^{\circ} \mathrm{C}$ & $1350^{\circ} \mathrm{C}$ & $1300^{\circ} \mathrm{C}$ & $\begin{array}{l}\text { High } \\
\text { temp. }\end{array}$ & $\begin{array}{l}\text { Low } \\
\text { temp. } 1\end{array}$ & $\begin{array}{l}\text { Low } \\
\text { temp. } 2\end{array}$ & $\begin{array}{l}\text { High } \\
\text { temp. }\end{array}$ & $\begin{array}{l}\text { Low } \\
\text { temp. } 1\end{array}$ & $\begin{array}{l}\text { Low } \\
\text { temp. } 2\end{array}$ & \\
\hline \multirow{6}{*}{$A-1$} & 0.64 & 5.00 & 34.52 & 55.20 & - & 26.758 & - & - & 12.265 & - & - & - \\
\hline & $"$ & 10.00 & 17.85 & 23.51 & 39.75 & 10.189 & 17.915 & 5.613 & 4.048 & 8.155 & 1.488 & $1350.6,1318.4$ \\
\hline & $"$ & 15.00 & 11.14 & 18.29 & 24.40 & 8.085 & 10.590 & - & 3.056 & 4.447 & - & 1280.9 \\
\hline & $"$ & 20.00 & 4.89 & 6.22 & 8.63 & 6.681 & 9.008 & 123.774 & 2.747 & 3.983 & 67.709 & $1352.5,1281.3$ \\
\hline & $"$ & 25.00 & 1.52 & 2.73 & 3.44 & 18.687 & 7.016 & 11.930 & 9.482 & 3.304 & 5.996 & $1357.3,1302.2$ \\
\hline & $"$ & 30.00 & 1.71 & 1.88 & 2.80 & - & 12.580 & - & 2.340 & 6.413 & - & 1358.0 \\
\hline \multirow{6}{*}{ A-2 } & 0.80 & 5.00 & 22.46 & - & - & 89.818 & - & - & 44.963 & - & - & - \\
\hline & $"$ & 10.00 & 9.29 & 23.14 & - & 12.336 & 26.872 & 120.097 & 5.394 & 12.986 & 62.559 & $1350.6,1318.4$ \\
\hline & $"$ & 15.00 & 1.61 & 7.28 & 12.23 & 26.404 & 10.066 & - & 13.165 & 44.333 & - & 1341.8 \\
\hline & $"$ & 20.00 & 1.52 & 2.82 & 3.27 & 32.231 & 3.778 & 10.664 & 16.444 & 1.559 & 5.202 & $1351.8,1263.2$ \\
\hline & $"$ & 25.00 & 1.50 & 2.20 & 3.31 & 10.490 & - & - & 5.235 & - & - & - \\
\hline & $"$ & 30.00 & 1.81 & 2.95 & 4.94 & 13.257 & 39.196 & - & 6.580 & 21.324 & - & 1261.4 \\
\hline \multirow{6}{*}{ A-3 } & 0.93 & 5.00 & 14.74 & 183.64 & - & 67.232 & - & - & 33.470 & - & - & - \\
\hline & $"$ & 10.00 & 4.95 & 10.42 & 28.04 & 25.098 & 30.157 & - & 12.295 & 15.122 & 一 & 1271.7 \\
\hline & $"$ & 15.00 & 1.97 & 2.88 & 5.02 & 11.013 & 15.800 & 一 & 5.373 & 8.031 & - & 1280.9 \\
\hline & " & 20.00 & 1.17 & 1.90 & 4.52 & 6.486 & 22.427 & 9.758 & 3.350 & 11.658 & 4.631 & $1371.1,1282.9$ \\
\hline & $"$ & 25.00 & 1.30 & 1.47 & 1.88 & 6.002 & 15.443 & 53.054 & 3.001 & 8.174 & 30.264 & $1301.7,1196.4$ \\
\hline & $"$ & 30.00 & 1.30 & 2.12 & 2.61 & 19.854 & 6.754 & 25.888 & 10.144 & 3.283 & 148.999 & $1374.7,1220.2$ \\
\hline \multirow{6}{*}{ A-4 } & 1.10 & 5.00 & 7.54 & 14.40 & 88.84 & 10.144 & 46.722 & - & 4.355 & 23.684 & - & 1370.5 \\
\hline & $"$ & 10.00 & 4.08 & 6.67 & 19.25 & 15.627 & 30.285 & 16.002 & 7.469 & 15.289 & 7.504 & $1344.7,1310.6$ \\
\hline & $"$ & 15.00 & 2.89 & 6.35 & 15.49 & 21.857 & 45.197 & - & 10.802 & 23.943 & - & 1259.8 \\
\hline & $"$ & 20.00 & 1.54 & 2.36 & 4.16 & 10.831 & 16.600 & 27.644 & 5.398 & 8.454 & 14.448 & $1352.3,1317.2$ \\
\hline & $"$ & 25.00 & 2.04 & 4.51 & 15.44 & 28.673 & 15.638 & 44.514 & 14.495 & 7.383 & 23.542 & $1308.7,1269.2$ \\
\hline & $"$ & 30.00 & 3.04 & 6.57 & 20.01 & 21.666 & 37.670 & 一 & 10.689 & 19.407 & - & 1311.2 \\
\hline \multirow{6}{*}{$A-5$} & 1.32 & 5.00 & 85.63 & 106.36 & 194.09 & 5.579 & 52.383 & - & 0.940 & 26.368 & - & 1315.5 \\
\hline & $"$ & 10.00 & 47.38 & 60.22 & 68.46 & 5.078 & 16.869 & 47.108 & 0.929 & 7.430 & 25.474 & $1294.0,1173.3$ \\
\hline & $"$ & 15.00 & 30.42 & 75.55 & - & 24.931 & - & - & 11.378 & - & - & - \\
\hline & " & 20.00 & 14.11 & - & - & 64.219 & - & - & 31.979 & - & - & - \\
\hline & $"$ & 25.00 & 8.66 & 23.60 & 197.91 & 27.078 & 55.945 & - & 13.040 & 28.366 & - & 1352.5 \\
\hline & " & 30.00 & 20.41 & 62.40 & - & 45.119 & 5.326 & 48.298 & 21.950 & 1.170 & 23.882 & $1379.7,1359.9$ \\
\hline \multirow{6}{*}{ A-6 } & 1.45 & 5.00 & - & - & - & - & - & - & - & - & - & - \\
\hline & $"$ & 10.00 & - & - & - & - & - & - & - & - & - & - \\
\hline & $"$ & 15.00 & 57.51 & - & - & - & - & - & - & - & - & - \\
\hline & $"$ & 20.00 & 40.00 & - & - & - & - & - & - & - & - & - \\
\hline & $"$ & 25.00 & 49.10 & - & - & - & - & - & - & - & 一 & - \\
\hline & $"$ & 30.00 & 63.10 & - & - & - & - & - & - & - & - & - \\
\hline
\end{tabular}

Notice; - : immeasureable

of minimum values of $\eta$ extends to lower basicity with increasing content of $\mathrm{MnO}$. Moreover, the ratio of $\eta$ to basicity increases with the content of $\mathrm{MnO}$.

(3) From the results obtained where the content of $\mathrm{Al}_{2} \mathrm{O}_{3}$ was kept at $6 \%$, iso-viscous graphs of the slag of $\mathrm{MnO}-\mathrm{CaO}-\mathrm{SiO}_{2}-\mathrm{Al}_{2} \mathrm{O}_{3}$ system are made and shown in Fig. 3. If the results in Fig. 3 are compared with our equi-conductive graphs of $\mathrm{Fe}-\mathrm{Mn} \mathrm{slag}^{2}$, a very close relation is seen between both graphs.

3.2 Effects of $\mathrm{Al}_{2} \mathrm{O}_{3} \quad$ The results of measurements on the effect of $\mathrm{Al}_{2} \mathrm{O}_{3}$ at 1400,1350 and $1300^{\circ} \mathrm{C}$ are shown in Table 3. The relation between $\log \eta$ and basicity is classified according to the $\mathrm{Al}_{2} \mathrm{O}_{3}$ contents and the results obtained are given in Fig. 5. From the results shown in Table 3 and Fig. 5, the effect of $\mathrm{Al}_{2} \mathrm{O}_{3}$ is concluded as the following items.

(1) Under the constant content of $\mathrm{Al}_{2} \mathrm{O}_{3}, \eta$ decreases with increasing content of $\mathrm{Al}_{2} \mathrm{O}_{3}$; while, the $\mathrm{Al}_{2} \mathrm{O}_{3}$ content comes over the certain value, $\eta$ increases rapidly. The content of $\mathrm{Al}_{2} \mathrm{O}_{3}$ giving the minimum value of $\eta$ is nearly $10 \%$ in the range of basicity $0.65 \sim 1.0$; it is changed with the increase of basicity, and is nearly $15 \%$ in the range of rather higher basicity, nearly $1.3 \sim 1.45$. 


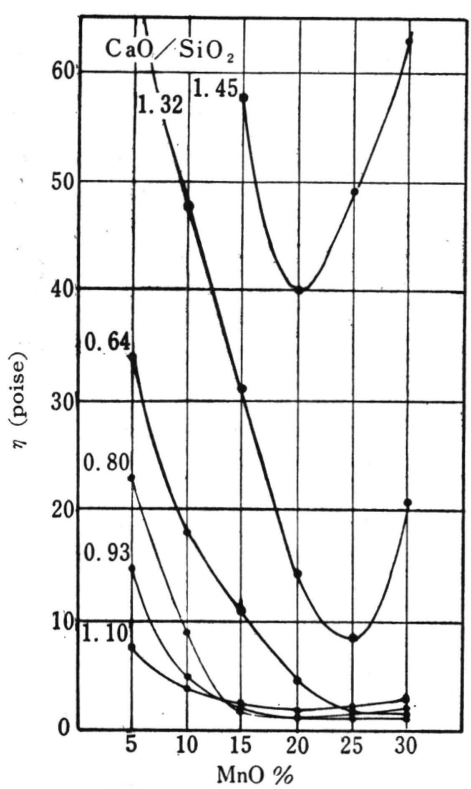

Fig. 1 Effect of $\mathrm{MnO}$ content on $\eta$

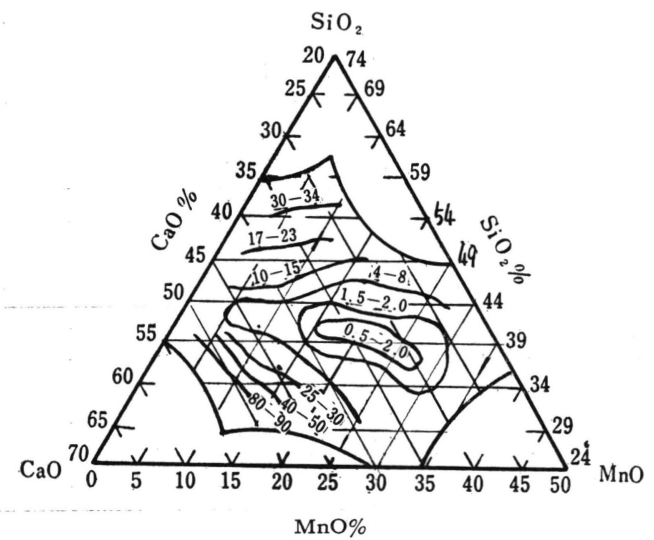

Fig. 3 Iso-viscosity diagram at $1400^{\circ} \mathrm{C}$ $\left(\mathrm{Al}_{2} \mathrm{O}_{3} 6 \%\right)$

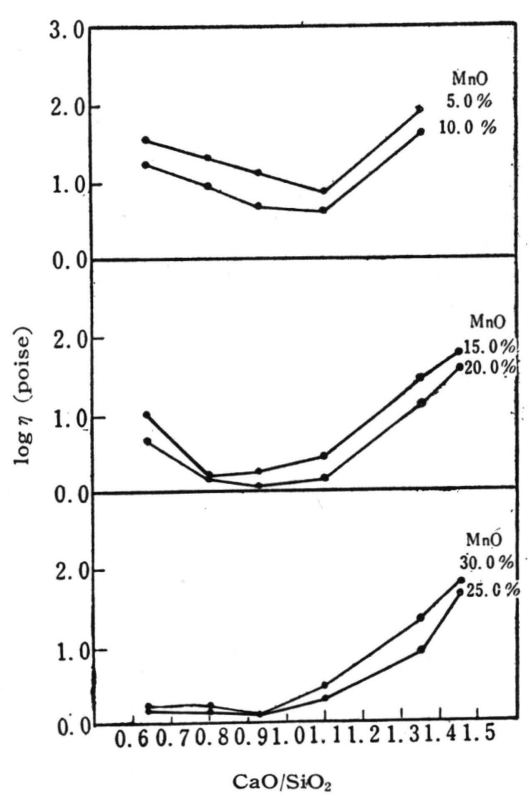

Fig. 2 Relation among basicity, $\log \eta$ and $\mathrm{MnO}$ content

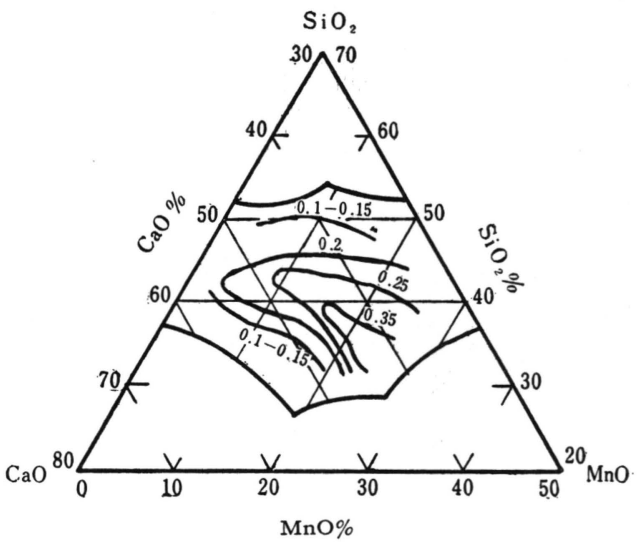

Notice : The diagram is plotted by weight $\%$ of three components $\left(\mathrm{CaO}, \mathrm{SiO}_{2}, \mathrm{MnO}\right)$

Fig. 4 Iso-viscosity diagram at $1400^{\circ} \mathrm{C}$ $\left(\mathrm{Al}_{2} \mathrm{O}_{3} 6 \%\right)$

(2) As seen in Fig. 5, the effect of increase of $\mathrm{Al}_{2} \mathrm{O}_{3}$ content on the basicity is remarkably reduced.

(3) From the results obtained, iso-viscous graphs of $\mathrm{MnO}-\mathrm{CaO}-\mathrm{SiO}_{2}-\mathrm{Al}_{2} \mathrm{O}_{3}$ system are made when $\mathrm{MnO}$ is kept at $10 \%$, and the results are shown in Fig. 6.

\subsection{Effects of temperature and activation Energy}

(1) The effect of temperature on $\eta$ is the same as general tendencies of molten salts; that is, $\eta$ gradually increases with decreasing temperature to a certain value, and then a rapid increase of $\eta$ is seen with the crystallization of solid phase, which makes the measurement impossible.

(2) The relation between $\log \eta$ and $1 / T$ is definitely linear in every experiment. From this result, activation energy $Q$ and constant term $C$ are determined by Eq. (2), and they are shown in Tables 2 and 3. 
Table 3 Effect of $\mathrm{Al}_{2} \mathrm{O}_{3}$ Content

\begin{tabular}{|c|c|c|c|c|c|c|c|c|c|c|c|c|}
\hline \multirow{3}{*}{ Group } & \multirow{3}{*}{$\mathrm{CaO} / \mathrm{SiO}_{2}$} & \multirow{3}{*}{$\mathrm{Al}_{2} \mathrm{O}_{3}$} & \multirow{2}{*}{\multicolumn{3}{|c|}{$\eta$ (poise) }} & \multicolumn{6}{|c|}{$\ln \eta=Q_{1} R T+C$} & \multirow{3}{*}{$\begin{array}{l}\text { Inversion } \\
\text { points }\left({ }^{\circ} \mathrm{C}\right)\end{array}$} \\
\hline & & & & & & \multicolumn{3}{|c|}{$Q(\mathrm{kcal})$} & \multicolumn{3}{|c|}{$-C \cdot \log _{10} e$} & \\
\hline & & & $1400^{\circ} \mathrm{C}$ & $1350^{\circ} \mathrm{C}$ & $1300^{\circ} \mathrm{C}$ & $\begin{array}{l}\text { High } \\
\text { temp. }\end{array}$ & $\begin{array}{l}\text { Low } \\
\text { temp. } 1\end{array}$ & $\begin{array}{l}\text { Low } \\
\text { temp. } 2\end{array}$ & $\begin{array}{l}\text { High } \\
\text { temp. }\end{array}$ & \begin{tabular}{|l|} 
Low \\
temp. 1
\end{tabular} & $\begin{array}{l}\text { Low } \\
\text { temp. } 2\end{array}$ & \\
\hline \multirow{5}{*}{ B-1 } & 0.64 & 3.00 & 18.76 & - & - & 86.789 & - & - & 43.474 & - & - & - \\
\hline & $"$ & 6.00 & 17.85 & 23.51 & 37.75 & 10.189 & 17.915 & 5.613 & 4.048 & 8.155 & 1.488 & $1350.6,1318.4$ \\
\hline & $"$ & 10.00 & 8.06 & 17.77 & 33.29 & 15.683 & - & - & 7.077 & - & 一 & - \\
\hline & $"$ & 15.00 & 11.13 & 20.25 & 35.49 & 15.709 & 10.795 & 17.375 & 7.061 & 4.344 & 8.133 & $1288.2,1225.6$ \\
\hline & $"$ & 20.00 & 20.80 & 31.75 & 49.70 & 11.510 & 21.306 & - & 4.612 & 10.123 & - & 1260.8 \\
\hline \multirow{5}{*}{ B -2 } & 0.80 & 3.00 & 8.94 & 25.55 & - & 14.085 & 22.784 & 70.497 & 6.319 & 10.860 & 36.078 & $1380.4,1359.9$ \\
\hline & $"$ & 6.00 & 9.29 & 23.14 & - & 12.336 & 26.872 & 120.097 & 5.394 & 12.986 & 62.559 & 1379.3 \\
\hline & $"$ & 10.00 & 5.52 & 7.31 & 11.81 & 9.019 & 12.205 & - & 3.920 & 5.64 & 一 & 1350.3 \\
\hline & $"$ & 15.00 & 8.35 & 10.53 & 16.72 & 7.045 & 14.470 & - & 2.718 & 6.715 & - & 1330.1 \\
\hline & $"$ & 20.00 & 12.16 & 19.36 & 32.73 & 13.777 & 5.300 & 11.781 & 6.039 & 1.816 & 5.207 & $1287.7,1197.0$ \\
\hline \multirow{5}{*}{ B-3 } & 0.93 & 3.00 & 10.18 & 46.06 & - & 50.606 & 192.350 & - & 25.256 & 101.569 & - & 1330.0 \\
\hline & $"$ & 6.00 & 4.95 & 10.46 & 28.04 & 25.098 & 30.157 & - & 12.295 & 15.122 & - & 1271.7 \\
\hline & $"$ & 10.00 & 4.70 & 6.04 & 8.60 & 4.811 & 11.103 & 23.076 & 1.780 & 5.149 & 11.876 & $1338.9,1260.3$ \\
\hline & $"$ & 15.00 & 7.62 & 10.16 & 15.39 & 7.314 & 12.747 & 33.836 & 2.898 & 5.778 & 19.002 & $1355.4,1103.3$ \\
\hline & $"$ & 20.00 & 8.63 & 12.56 & 18.50 & 10.520 & 21.317 & 14.382 & 5.032 & 10.366 & 65.334 & $1312.3,1288.8$ \\
\hline \multirow{5}{*}{ B -4 } & 1.10 & 3.00 & 3.62 & 7.79 & 19.92 & 23.916 & 13.603 & - & 11.833 & 6.105 & - & 1280.8 \\
\hline & $"$ & 6.00 & 4.08 & 6.67 & 19.25 & 15.627 & 30.285 & 16.002 & 7.469 & 15.289 & 7.505 & $1344.7,1310.6$ \\
\hline & $"$ & 10.00 & 3.42 & 5.90 & 8.82 & 15.783 & 2.533 & 49.114 & 7.610 & 0.433 & 26.783 & $1320.2,1252.6$ \\
\hline & $"$ & 15.00 & 4.69 & 5.35 & 9.53 & 2.678 & 21.707 & 4.751 & 0.716 & 10.807 & 1.624 & $1354.3,1320.4$ \\
\hline & $"$ & 20.00 & 18.73 & 27.17 & 51.71 & 13.915 & 一 & - & 5.904 & - & - & - \\
\hline \multirow{5}{*}{ B -5 } & 1.32 & 3.00 & 51.44 & 71.42 & 117.40 & 8.855 & 22.310 & - & 2.864 & 10.105 & - & 1330.8 \\
\hline & $"$ & 6.00 & 47.38 & 60.22 & 68.46 & 5.078 & 16.869 & 47.108 & 0.930 & 7.430 & 25.474 & $1294.0,1173.3$ \\
\hline & $"$ & 10.00 & 10.63 & 39.93 & 63.54 & 50.091 & 12.949 & 25.807 & 24.809 & 5.713 & 12.700 & $1371.2,1290.9$ \\
\hline & $"$ & 15.00 & 9.00 & 9.79 & 33.31 & 3.248 & 66.447 & 33.132 & 0.731 & 34.906 & 16.593 & $1323.0,1297.1$ \\
\hline & $"$ & 20.00 & 17.61 & 20.74 & 44.43 & 2.781 & 18.663 & 一 & 0.193 & 一 & 一 & 1360.0 \\
\hline \multirow{5}{*}{ B-6 } & 1.45 & 3.00 & - & 一 & - & - & - & - & - & - & - & - \\
\hline & $"$ & 6.00 & - & - & - & - & - & - & - & - & - & - \\
\hline & " & 10.00 & 28.85 & 59.98 & - & 20.039 & - & - & 8.877 & - & - & - \\
\hline & " & 15.00 & 11.75 & 40.00 & - & 33.531 & - & - & 16.227 & - & - & - \\
\hline & $"$ & 20.00 & 30.20 & 70.96 & - & 23.385 & - & - & 10.583 & - & - & - \\
\hline
\end{tabular}

Notice; - : immeasureable

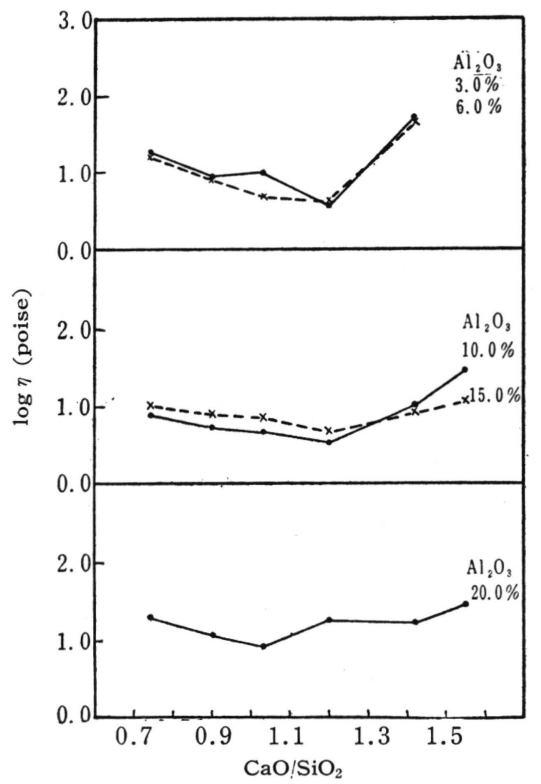

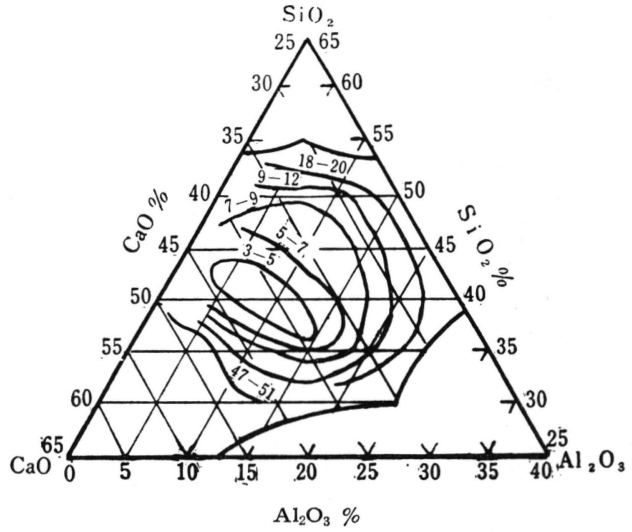

Fig. 6 Iso-viscosity diagram at $1400^{\circ} \mathrm{C}$ $\left(\mathrm{Al}_{2} \mathrm{O}_{3} 6 \%\right)$

Fig. 5 Relation among basicity, $\log \eta$ and $\mathrm{Al}_{2} \mathrm{O}_{3}$ content 


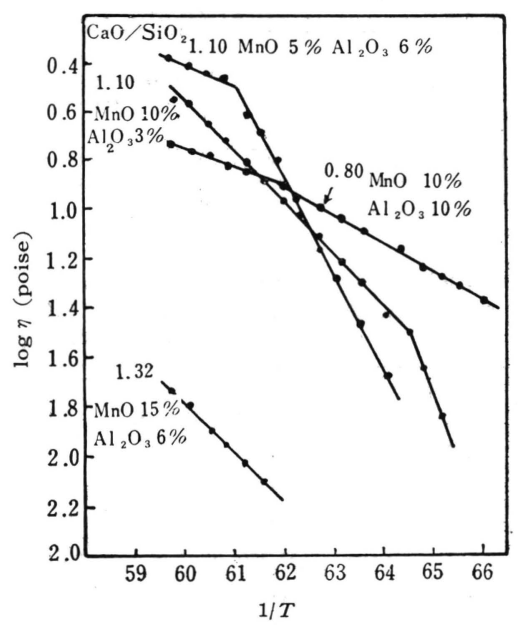

Fig. 7 Examples of relation between $\log \eta$ and $1 / T$

$$
\ln \eta=Q / R T+C
$$

(3) In almost all samples, a bend point is seen on the linear line of $\log \eta-1 / T$ at higher temperatures than that at which a rapid increase of $\eta$ due to the solidification is observed. With the exception of few cases, the value of activation energy at the higher temperatures than that corresponding to the bend is $3 \sim 20 \mathrm{kcal} / \mathrm{g} \cdot \mathrm{mol}$, which is rather small.

The exceptional case of higher values of $Q$ is supposed to be due to the fact that the bend is located at the higher temperatures than $1400^{\circ} \mathrm{C}$. Examples of relation between $\log \eta$ and $1 / T$ of samples with the higher value of $Q$ are shown in Fig. 7. in comparison with those of ordinary values.

(Received Apr. 14, 1960).

\section{Literature :}

1) I. Tanabe, K. Oku, J. Electrochem. Soc. Japan 28, 681 (1960).

2) I. Tanabe, K. Oku, J. Japan Inst. Metals 22, 114 (1958). 